\title{
The Degenerating Sex: Female Sterilisation, Medical Authority and Racial Purity in Catholic Brazil
}

\author{
CASSIA ROTH * \\ Department of History, LeConte Hall, University of Georgia, 250 Baldwin Ave., Athens, \\ GA 30602, USA
}

\begin{abstract}
This article examines female sterilisation practices in early twentieth-century Rio de Janeiro, Brazil. It argues that the medical profession, particularly obstetricians and psychiatrists, used debates over the issue to solidify its moral and political standing during two political moments of Brazilian history: when the Brazilian government separated church and state in the 1890s and when Getúlio Vargas's authoritarian regime of the late 1930s renewed alliances with the Catholic church. Shifting notions of gender, race, and heredity further shaped these debates. In the late nineteenth century, a unified medical profession believed that female sterilisation caused psychiatric degeneration in women. By the 1930s, however, the arrival of eugenics caused a divergence amongst physicians. Psychiatrists began supporting eugenic sterilisation to prevent degeneration - both psychiatric and racial. Obstetricians, while arguing that sterilisation no longer caused mental disturbances in women, rejected it as a eugenic practice in regard to race. For obstetricians, the separation of sex from motherhood was more dangerous than any racial 'impurities', both phenotypical and psychiatric. At the same time, a revitalised Brazilian Catholic church rejected eugenics and sterilisation point blank, and its renewed ties with the Vargas regime blocked the medical implementation of any eugenic sterilisation laws. Brazilian women, nonetheless, continued to access the procedure, regardless of the surrounding legal and medical proscriptions.
\end{abstract}

Keywords: Brazil, Catholicism, Sterilisation, Race, Eugenics, Degeneration

This article explores how medical debates about female sterilisation shaped two political moments in Brazilian history: the 1890s, when the country's newfound republican government separated church and state and the medical profession became a powerful lobby in the public sphere; and the 1930s, when Getúlio Vargas's increasingly authoritarian regime both renewed ties with the Catholic church and integrated eugenics policy into

* Email address for correspondence: cassia.roth@uga.edu

The author would like to thank the three peer reviewers for their insightful comments on this article. She would also like to thank the editors of the special issue. Part of the research and writing of this article were supported by Fulbright, the National Science Foundation, and the European Union (Marie Sklodowska-Curie 747374). 
governmental platforms. It traces female sterilisation in relation to shifting notions of heredity and race within the broader context of a modernising Catholic nation, focusing on the capital of Rio de Janeiro.

In 1889, just a year after Brazil became the last country in the western hemisphere to abolish slavery, a bloodless military coup overthrew the Brazilian monarchy (1821-89) and instituted a republican form of government (the First Republic, 1889-1930). Republican officials separated church and state, weakening the church's institutional power and opening up political, social and cultural space for new authorities, including physicians, to take control of debates previously dominated by religious authorities. ${ }^{1}$ Of course, Brazilian physicians, like their religious brethren, had pronounced women's reproduction as the foundation of the nation throughout the nineteenth century, emphasising women's natural roles as mothers. ${ }^{2}$ In the First Republic, however, the Brazilian medical field seized upon a new political climate to insert itself as an important political actor in relation to the family.

To become dominant figures on gender and reproduction, physicians could not simply co-opt religious rhetoric. They also had to police the boundaries of their profession to legitimate their moral standing. During the first decade of the republican period, the topics of gender, reproduction and medical authority came to the fore when, in 1893, a licenced Italian physician practising in Rio de Janeiro, Abel Parente, advertised a 'secret' female sterilisation technique in the city's newspapers. ${ }^{3}$ At the request of some of his colleagues, the police investigated Parente. ${ }^{4}$ As the press published stories of the rogue physician, a consolidating medical profession couched longstanding religious arguments on the importance of traditional gender roles in the language of science to condemn the physician. Parente, who had advertised his techniques without first going through peer review, presented an enemy within, a practitioner who threatened physicians' ability to define and defend societal standards. ${ }^{5}$

Although the police investigated Parente, they did not have enough evidence to bring him to trial. In 1900, however, the issue of Parente's sterilisation practice resurfaced. In that year, one of Parente's female patients allegedly entered into a state of psychosis after his treatments. His colleagues, in particular obstetricians and psychiatrists, uniformly denounced him to authorities, and this time the state, using the physical evidence of his female patient's body, brought him to trial for malpractice. ${ }^{6}$

\footnotetext{
${ }^{1}$ On church-state relations, see Mala Htun, Sex and the State: Abortion, Divorce and the Family Under Latin American Dictatorships and Democracies (New York: Cambridge University Press, 2003), 30-6.

2 Jurandir Freire Costa, Ordem médica e norma familiar, 2nd edn (Rio de Janeiro: Edições Graal, 1983); Ana Paula Vosne Martins, Visões do feminino: a medicina da mulher nos séculos XIX e XX (Rio de Janeiro: Editora Fiocruz, 2004); Okezi T. Otovo, Progressive Mothers, Better Babies: Race, Public Health, and the State in Brazil, 1850-1945 (Austin: University of Texas Press, 2016); Fabíola Rohden, Uma ciência da diferença: sexo e gênero na medicina da mulher, 2nd edn (Rio de Janeiro: Editora Fiocruz, 2009); Cassia Roth, A Miscarriage of Justice: Women's Reproductive Lives and the Law in Early Twentieth-Century Brazil (Stanford, CA: Stanford University Press, 2020); Luiz Lima Vailati, A morte menina: infância e morte infantil no Brasil dos oitocentos (Rio de Janeiro e São Paulo) (São Paulo: Alameda, 2010).

3 Abel Parente, 'A minha descoberta de prevenir para sempre a concepção', Gazeta de Noticias, 20 January 1893, 2; Abel Parente, 'A minha descoberta de prevenir para sempre a concepção', Jornal do Commercio, 7 February $1893,3$.

${ }^{4}$ See the reporting in Jornal do Brasil, O Paiz, Gazeta de Noticias and Jornal do Commercio, particularly between February and April 1893.

${ }^{5}$ Rohden, Uma ciência da diferença, 184-6.

${ }^{6}$ See the reporting in Jornal do Brasil, Gazeta de Noticias, A Noticia, Correio de Manhã, Jornal do Commercio, and $O$ Paiz, particularly between January and August 1901.
} 
During both the 1893 investigation and the later trial, the medical profession's condemnation of sterilisation dovetailed with their intensifying discussion over the future of the Brazilian 'race' and nation. In a country that had only recently abolished slavery, and in a period when scientific racist theories were swirling across the globe, Brazilian politicians, physicians and legislators debated European notions of racial degeneracy both as an individual characteristic based on phenotype and as part of 'the collective Brazilian citizenry'. ${ }^{7}$ While some leading thinkers supported the European view that miscegenation led to a degenerate population, most Brazilian intellectuals sustained the idea that racial mixing would whiten the Brazilian race. ${ }^{8}$ But degeneracy in Brazil was never solely about individual understandings of race. ${ }^{9}$ Physicians also discussed the theory in relation to the future of the Brazilian populace at large, and many supported nineteenth-century medical discussions of cumulative hereditary psychiatric decline in families in which deviant traits poisoned the body politic over generations. ${ }^{10}$

In both the 1893 investigation and the 1901 trial, race as phenotype was subsumed within obstetricians' and psychiatrists' discussions of degeneracy as a gendered psychiatric trait. Scholars have demonstrated how competing theories of degeneracy put a newfound emphasis on motherhood and childbearing. ${ }^{11}$ Here, however, I demonstrate how gendered theories changed physicians' understandings of degeneracy itself. For the doctors deliberating sterilisation in the Parente trial, potential degeneracy was located in the female body - based on the woman's genealogy but independent of her phenotypical makeup. By impeding the female body from performing its 'true' function - motherhood - sterilisation caused grave physical and psychological consequences and triggered any existing but latent degenerative traits. In a period when gynaecologists and obstetricians had firmly linked women's bodies to their sexual function and described those bodies as 'unstable' and prone to hysteria, intervening in any 'natural' process was dangerous. ${ }^{12}$ Sterilisation, which disrupted the natural maternal order, caused, not prevented, degeneration. Disconnecting women's sexuality from motherhood threatened traditional gender roles, which resulted in psychological disturbances. The Parente debate, I contend, demonstrates how psychiatrists and obstetricians emphasised how the gendered aspects of degeneracy were just as, if not more, threatening to the nation than racial ones. Moreover, simple understandings of heredity (even if incorrect) were not enough to explain gendered degeneracy. Rather, unsanctioned medical intervention like sterilisation could trigger a woman's psychiatric hereditary traits that otherwise would have remained dormant. Physicians deployed gender in the Parente affair as a primary lens - although not the only one - to mark degeneration.

In the decades following the second Parente question, obstetricians and psychiatrists continued to debate sterilisation in relation to nebulous notions of heredity tied to race, gender and psychiatry. They also maintained their authoritative claim over familial issues

7 Okezi Otovo, 'Marrying "Well": Debating Consanguinity, Matrimonial Law, and Brazilian Legal Medicine, 1890-1930', Law and History Review, 33, 3 (2015), 723.

${ }^{8}$ Lilia Moritz Schwarcz, O espetáculo das raças: cientistas, instituições, e questão racial no Brasil, 1870-1930 (São Paulo: Companhia das Letras, 1993); Thomas E. Skidmore, Black into White: Race and Nationality in Brazilian Thought, rev. edn (Durham, NC: Duke University Press, 1993).

${ }^{9}$ Otovo, op. cit. (note 7), 722.

${ }^{10}$ Dain Borges, “'Puffy, Ugly, Slothful and Inert”: Degeneration in Brazilian Social Thought, 1880-1940', Journal of Latin American Studies, 25, 2 (1993), 236.

${ }^{11}$ Borges, op. cit. (note 10); Otovo, op. cit. (note 7); Julyan G. Peard, Race, Place, and Medicine: The Idea of the Tropics in Nineteenth-Century Brazilian Medicine (Durham, NC: Duke University Press, 1999).

${ }^{12}$ Martins, op. cit. (note 2), 110-11. 
in the public sphere. At the same time, new scientific ideologies and medical technologies and a resurgent Catholic church reframed these discussions. To begin with, the arrival of eugenics in the late 1910s and early 1920s sharpened the debate over degeneracy and sterilisation. The majority of Brazilian eugenicists adhered to a neo-Lamarckian theory of heredity, which purported that acquired traits were inheritable - environmental influences could alter a person's genetic makeup (transmutation), which could be passed on to offspring - and promoted hygienic education. ${ }^{13}$

Eugenicists' positions also depended on their medical speciality. Brazilian obstetricians, for example, overwhelmingly supported Lamarckian notions, which resulted in their rejection of racial discussions of degeneracy. If miscegenation was whitening the population, and eugenicists were training all women to reproduce responsibly, then no woman, no matter her race or class, should control her fertility. ${ }^{14}$ Moreover, by the 1920s they no longer argued that sterilisation caused degeneracy. They simply rejected it as a eugenic practice altogether. Improving maternal-infant health was more important than restricting certain populations from reproducing. Medical advances such as tubal ligations allowed obstetricians, moreover, both to reject sterilisation procedures in relation to degeneracy and to incorporate new surgical techniques into their clinical practice. By disconnecting sterilisation from degeneration and by practising new surgical methods, obstetricians created a space for them, and only them, to practise it.

Nevertheless, not all physicians active in the eugenics movement held the same theoretical positions of their obstetric colleagues. In the 1930s, the racist eugenics of the US and Nazi Germany influenced the Brazilian scientific community, particularly psychiatrists, who proposed negative eugenic measures including the sterilisation of the catch-all phrase 'degenerates' and condemned racial mixing. ${ }^{15}$ Psychiatrists believed both male and female sterilisation would prevent degeneracy, both in its psychiatric and racial forms. While some eugenicists supported compulsory sterilisation, their proposals never made it into law. When Getúlio Vargas took over the presidency in 1930, he courted a closer relationship with the Catholic church, which prevented the implementation of extreme eugenic policies. As Vargas became more authoritarian, however, he also incorporated less-intrusive eugenic principles into policy, including eugenic education and prenuptial examinations. ${ }^{16}$ Much like the obstetricians opposed to more negative programmes, the Vargas administration viewed supporting traditional gender roles - the nuclear family with a male breadwinner and female reproducer - as key to improving the population's quality and quantity. ${ }^{17}$

Scholars have explored the Parente debate from various angles: the medical profession's efforts to insert themselves into social and moral discussions; physicians' elision of sterilisation with abortion; the scientific conviction that intervening in a woman's

\footnotetext{
13 Otovo, op. cit. (note 7), 721-2 n57; Nancy Leys Stepan, The Hour of Eugenics: Race, Gender, and Nation in Latin America (Ithaca, NY: Cornell University Press, 1991), 67-76.

${ }^{14}$ Roth, op. cit. (note 2).

15 Sandra Caponi, 'Degeneración y eugenesia en la historia de la siquiatría brasileña: Renato Kehl y los heredodegenerados', História, Ciências, Saúde - Manguinhos, 25, Supl. (2018), 159-78; Vanderlei Sebastião de Souza, 'A eugenia brasileira e suas conexões internacionais: uma análise a partir das controvérsias entre Renato Kehl e Edgard Roquette-Pinto, 1920-1930', História, Ciências, Saúde - Manguinhos, 23, Supl. (2016), 93-110; Robert Wegner and Vanderlei Sebastião de Souza, 'Eugenia "negativa", psiquiatria e catolicismo: embates em torno da esterilização eugênica no Brasil', História, Ciências, Saúde - Manguinhos, 20, 1 (2013), 263-88.

${ }^{16}$ Stepan, op. cit. (note 13), 126-7.

17 Susan K. Besse, Restructuring Patriarchy: The Modernization of Gender Inequality in Brazil, 1914-1940 (Chapel Hill: University of North Carolina Press, 1996); Otovo, op. cit. (note 2).
} 
reproductive organs could cause mental upset; the subordination of women's reproductive bodies to the national good; the male public's fear of separating female sexuality from procreation; and increased medical preoccupations about the quality of the Brazilian population. ${ }^{18}$ Yet none have traced the issue of female sterilisation in relation to theories of heredity and racial fitness over an extended period of state expansion, changing churchstate relations and medical debate over racial and gendered aspects of the Brazilian population. This article situates the Parente case within a longer scientific and political trajectory, first analysing it relative to late nineteenth-century political and legal changes to both church and medical authority. It then examines the ideologies of race and gender that underpinned medical discussions of degeneracy and female sterilisation in republican Brazil, arguing that physicians' concerns over sterilisation - particularly those within the professionalising fields of obstetrics and psychiatry - were part of an attempt to consolidate their profession using debates over the family. While both obstetricians and psychiatrists condemned sterilisation at the turn of the century, the arrival of eugenics in the 1910s and 1920s and a changing political landscape of the 1930s shifted physicians' positions, and a divergence appeared within the profession. Pro-sterilisation psychiatrists employed both psychiatric and racial definitions of degeneracy to argue for sterilisation to prevent degeneracy, highlighting their increased fears over the quality of the population. For their part, obstetricians and gynaecologists rejected the practice not because it caused degeneracy but because it threatened traditional gender roles. For women's health physicians, female autonomy was more dangerous than racial impurities, both phenotypical and psychiatric. Moreover, obstetricians, by rejecting sterilisation as a cause of 'degeneracy', justified practising the procedure within their teaching hospitals and clinical practice. Women, however, were not helpless patients. Despite both religious and medical rejection of unsanctioned female sterilisation, judicial records show that women accessed temporary sterilisation methods into the 1930s, and that the provision of that care had moved into the hands of midwives.

\section{Parente in the Papers}

Early republican medical debates on the gendered contours of sterilisation occurred within a shifting political, demographic and intellectual climate. When republicans overthrew the monarchy in 1889 , an elite group of leaders came to power. The First Republic was a democracy in name only, as it did not enfranchise the majority of the population. ${ }^{19}$ Despite this limited democratic expansion, the First Republic represented a marked shift in the relationship between church and state. Positivist doctrine influenced the organisers of the 1889 revolution, middle-class men who adhered to August Comte's doctrine of social evolution. Republican politicians thus supported the rational identification and implementation of so-called natural laws to ensure social order and modernise Brazil after

\footnotetext{
18 José Leopoldo Ferreira Antunes, Medicina, leis e moral: pensamento médico e comportamento no Brasil (1870-1930) (São Paulo: Editora UNESP, 1998), 52-8; Martins, op. cit. (note 2), 184-8; Leonardo Mendes and Renata Ferreira Vieira, 'O “caso Abel Parente," os homens de letras e a disseminação do saber científico nos primórdios da República', Revista Maracanan, 13 (December 2015), 127-45; Rohden, op. cit. (note 2), 173-220; Marinete dos Santos Silva, 'Reprodução, sexualidade e poder: as lutas e disputas em torno do aborto e da contracepção no Rio de Janeiro, 1890-1930', História, Ciências, Saúde - Manguinhos, 19, 4 (2012), 1241-54. 19 José Murilo de Carvalho, Os bestializados: o Rio de Janeiro e a República que não foi, 3rd edn (São Paulo: Companhia das Letras, 2004).
} 
the abolition of slavery. ${ }^{20}$ Positivist politicians were most influential immediately after the fall of the monarchy, when they wrote proposals including the separation of church and state that became part of the 1891 constitution. ${ }^{21}$

Physicians in particular held an important position in propagating the state's positivist initiatives. $^{22}$ Both their political participation - many practising physicians also held elected office - and their clinical contact with the population at large allowed them to serve as a conduit between elite ideology and the Brazilian population. ${ }^{23}$ The First Republic thus provided new political and societal avenues for the medical field, which, as a professional body, personal livelihood and political lobby, was consolidating as a social force. In the first several decades of the Republic, physicians established the boundaries of their profession, regulating who could be included within their ranks. Most physicians rejected religious influence in their clinical practice, although they did not disregard religion per se. Many leading obstetricians, for example, were ardent Catholics yet found no qualms criticising its influence in medical decisions. ${ }^{24}$

In this politically turbulent period, one in which medical preoccupations focused on maintaining traditional gender roles through the control of the female body, Abel Parente began advertising services for a 'secret' method of 'preventing conception'. ${ }^{25}$ Although his advertisements never described the procedure, it most likely involved the removal of a woman's uterine lining on a monthly basis, often with caustic substances or hot water. ${ }^{26}$ Parente's technique was impermanent (and probably painful) but perhaps safer than many sterilisation methods of the period. In the nineteenth century, physicians practised surgical techniques - including hysterectomies (the removal of the uterus), oophorectomies (the removal of both ovaries), ovariotomies (the partial removal of the ovary) and salpingectomies (the removal of one or both Fallopian tubes) - via abdominal surgeries. Laparotomies (abdominal incisions) were dangerous, and physicians resorted to these techniques as a last option, only if they had already opened the abdomen, often for a cesarean section. Most patients died from shock, infection or haemorrhage. ${ }^{27}$ By the time Parente began advertising, however, developments in Western medical techniques were changing the surgical landscape. The introduction of anaesthesia in mid-century, the

\footnotetext{
${ }^{20}$ Borges, op. cit. (note 10); Mariza Corrêa, As ilusões da liberdade: a Escola Nina Rodrigues e a antropologia no Brasil, 3rd edn (Rio de Janeiro: Editora Fiocruz, 2013), 12-13, 30-5; Todd A. Diacon, Stringing Together a Nation: Cândido Mariano da Silva Rondon and the Construction of Modern Brazil, 1906-30 (Durham, NC: Duke University Press, 2004), 80-2.

${ }^{21}$ Article 72, §3-7, Constituição da Republica dos Estados Unidos do Brazil acompanhada das leis organicas publicadas desde 15 de Novembro de 1889 (Rio de Janeiro: Imprensa Nacional, 1891), 25. On positivists' influence, see José Murilo de Carvalho, A formação das almas: o imaginário da República no Brasil, 2nd edn (São Paulo: Companhia das Letras, 2017), 127-40.

${ }^{22}$ Stepan, op. cit. (note 13), 41-2.

${ }^{23}$ Stepan, op. cit. (note 13), 46-7. On physicians as politicians, see Maria Renilda Nery Barreto, 'Dar à luz no Rio de Janeiro da belle époque: o nascimento das maternidades (1870-1920)', in Gisele Sanglard et al. (eds), Filantropos da nação: sociedade, saúde e assistência no Brasil e em Portugal (Rio de Janeiro: Editora Fundação Getúlio Vargas, 2015), 185-201; Otovo, op. cit. (note 7).

${ }^{24}$ See Fernando Magalhães, Lições de clinica obstetrica, 2nd edn (Rio de Janeiro: Livraria Castilho, 1922), 426.

25 See advertisements in Gazeta de Noticias: 7 September 1890, 2; 12 October 1890, 2; 26 October 1890, $2 ; 17$ November 1890, 2; 21 December 1890, 2; 16 August 1891, 2; Jornal do Commercio: 1 June 1890, 2; 31 August 1890, 2; 23 November 1890, 2; 30 November 1890, 1.

${ }^{26}$ For the treatment, see 'O caso Abel Parente na Academia de Medicina', Gazeta de Noticias, 1 December 1900, 1-2; 'Caso Abel Parente', Gazeta de Noticias, 10 February 1901, 2; 'O caso Abel Parente', Gazeta de Noticias, 14 February 1901, 2. See also Rohden, op. cit. (note 2), 206.

${ }^{27}$ Ian Robert Dowbiggin, The Sterilization Movement and Global Fertility in the Twentieth Century (New York: Oxford University Press, 2008), 22-3.
} 
widespread acceptance of aseptic techniques for preventing infection in the 1880 s and the professionalisation of gynaecology made abdominal surgeries including hysterectomies and oophorectomies safer, less painful and more common. ${ }^{28}$ Yet in an era before blood transfusions and antibiotics, any surgery remained dangerous, and many obstetricians and gynaecologists in Brazil lacked the clinical practise to adequately hone their surgical talents. ${ }^{29}$ Parente's temporary method was easier to perform, and it guaranteed a consistent monetary stream from women who had to come back monthly for treatments.

The state investigated Parente in 1893 for his advertisements, and brought him to trial in 1901 for allegedly causing mental psychosis in one of his female patients. As scholars have argued, physicians used the dispute to insert themselves as the main actors not only in scientific debates but also in larger societal discussions that were formerly the territory of the church. ${ }^{30}$ But part of physicians' response was about policing their own professional boundaries, thus strengthening the exact position they hoped to win from church authorities. Obstetricians, psychiatrists, hygienists and medico-legal physicians wholeheartedly attacked Parente's decision to advertise the procedure without first discussing it within the larger medical community. ${ }^{31}$ It was not solely about Parente's unprofessional behaviour, but rather how his comportment reflected back on the profession as a whole. It is telling that when physicians first condemned Parente in 1893, they did so in the realm of organised medicine, with raucous debating occurring in the halls of the National Academy of Medicine, the country's premier medical body. ${ }^{32}$ Soon, however, physicians brought their complaints to the city's police force, who then investigated. ${ }^{33}$

In their statements to the police, colleagues were outraged that Parente had not submitted his procedure to peer review before advertising it in the newspapers. ${ }^{34}$ In his expert testimony during the 1893 investigation, for example, the famed medico-legal physician Agostinho José de Souza Lima argued that even if Parente was not breaking any criminal laws, he was violating professional standards. Parente, according to Lima, was 'assuming a responsibility that escapes the competence and individual attribution of one physician'. ${ }^{35}$ Parente's 'secret' practice threatened the larger profession. When the pharmacist Furquim Werneck testified against Parente in 1901, he described his methods as unscientific: 'There is nothing serious nor scientific in that process . . he lacks the most trivial and elementary qualities of a serious observer. ${ }^{36}$

Medical debates and extensive newspaper articles demonstrate that this was not the first time that Parente had clashed with his medical colleagues. ${ }^{37}$ The published proceedings

\footnotetext{
${ }^{28}$ Ibid., 21-3.

29 On training, see Martins, op. cit. (note 2), 142-51; Rohden, op. cit. (note 2), 71-81.

${ }^{30}$ Martins, op. cit. (note 2), 185-7; Rohden, op. cit. (note 2), 184.

31 'Ao Sr. Chefe de policia', Gazeta de Noticias, 15 August 1892, 2; 'Inquerito', Jornal do Commercio, 5 February 1893, 2; Gazeta de Noticias, 5 February 1893, 1; 'Sociedade de Hygiene do Brasil', Gazeta de Noticias, 19 February 1893, 2. See also Mendes and Vieira, op. cit. (note 18), 130; Rohden, op. cit. (note 2), 177.

32 'Esterilidade da mulher,' O Paiz, 16 February 1893, 1; Hugo F. Werneck, 'Processo secreto de esterilisação da mulher: documentos para sua historia', Revista de Gynecologia e D'Obstetricia do Rio de Janeiro, 2 (AugustDecember 1908), 1.

${ }^{33}$ See the following coverage: $O$ Paiz, 10 February 1893, 1; 'A esterilidade', $O$ Paiz, 22 February 1893, 1; 'A esterilidade', O Paiz, 24 February 1893, 2; O Paiz, 10 March 1893, 2; 'Esterilidade', O Paiz, 22 March 1893, 1; O Paiz, 25 April 1893, 1; 'A concepção', O Paiz, 30 May 1893, 1.

34 Werneck, op. cit. (note 32), 4-33.

35 O Paiz, 10 February 1893, 1 (emphasis mine).

${ }^{36}$ Furquim Werneck in Werneck, op. cit. (note 32), 2.

${ }^{37}$ See the heated debate between Parente and Carlos Teixeira in $O$ Brazil-Medico over uterine cancer and hysterectomies in 1888, and 'Questão de honra', O Paiz, 1 November 1908, 2.
} 
from association meetings and letters to the editor show a professional rabble-rouser. He argued that his colleagues had stolen his method of combating yellow fever. ${ }^{38} \mathrm{He}$ accused other physicians of plagiarism, and, in response, was sued for slander. ${ }^{39}$ By 1893 , perhaps physicians were upset that they had already let Parente into their professional ranks. ${ }^{40}$ But Parente was not simply a licenced physician, he was a popular one too, with an impressive clientele in Rio de Janeiro. ${ }^{41}$ His contentious words surrounding yellow fever or asepsis in childbirth clearly ruffled his colleagues' professional feathers, and he faced individual lawsuits for slander; but sterilisation was one step too far, and the state needed to intervene.

Although many members of the medical profession found more than sufficient evidence in the advertisements to condemn Parente, the courts depended on physical evidence, which they did not have, and the police closed the case. ${ }^{42}$ Many physicians remained unhappy with the decision. To them, Parente's independent medical practice threatened the consolidation of their profession and cast doubt over their moral standing in society. That he had decided to attack a subject which physicians viewed as their moral territory the family - made matters even worse.

The position of the few physicians who supported Parente in the early 1890s further underscore the true issue at stake: the boundaries of the medical profession. Obstetrician Erico Coelho, for instance, criticised his colleagues. By going to the police, physicians had opened the gates for legal professionals to decide 'a matter that [was] exclusively of scientific [concern]', thus allowing strangers into 'the intimate forum of the [medical] professional'. ${ }^{43}$ To Coelho, the Parente investigation had not solidified the boundaries of the profession but rather dissolved them. During the 1893 investigation, the director of the city's public health services, Francisco de Castro, also opined for Parente's innocence due to his status as a licenced medical professional. ${ }^{44}$ When Parente wrote to Castro asking if his advertisements were illegal, Castro responded with a definitive no: Parente, Castro argued, was 'a trained professional ... officially competent to practice medicine in all its branches'. 45

Soon after the 1893 investigation ended, Castro published the book $O$ invento Abel Parente [The Abel Parente Invention], a sweeping defence of Parente's practice. In it, he rejected physicians' condemnation of sterilisation as a form of abortion, argued that sterilisation was not a criminal offence under Brazilian penal law and contended that the practice increased public morality. Most importantly, Castro argued that if a married woman willingly consented to sterilisation for medical reasons, it was not a criminal act. 'She enjoys a right, that not one positive obligation ties to the right of another person, save, if married, those of the other spouse. ${ }^{46}$ On the surface, Castro gave agency to the woman

\footnotetext{
38 'A febre amarela', $O$ Paiz, 24 January 1896, 1; 'A febre amarela', O Paiz, 25 January 1896, 1; 'A Academia Nacional de Medicina e o serum-caldas', O Paiz, 23 April 1898, 2; 'A questão da febre amarela', O Paiz, 27 November 1898, 2; 'A febre amarela', $O$ Paiz, 11 February 1899, 2; 'A febre amarela', O Paiz, 20 February 1899, 2; O Paiz, 22 February 1899, 2.

39 'A vida forense', O Paiz, 27 April 1900, 2; 'A vida forense', O Paiz, 29 July 1900, 2.

40 Sociedade de Medicina e Cirurgia, 'Sessão em 1 de outubro de 1889', O Brazil-Medico, 4, 4 (1890), 30.

${ }^{41}$ Mendes and Vieira, op. cit. (note 18), 128-9.

42 'A concepção', $O$ Paiz, 30 May 1893, 1.

43 'Academia Nacional de Medicina', O Paiz, 27 April 1893, 2-3.

${ }^{44}$ Francisco de Castro, in Werneck, op. cit. (note 32), 4.

${ }^{45}$ Francisco de Castro, $O$ invento Abel Parente no ponto de vista do direito criminal, da moral publica e da medicina clinica (Rio de Janeiro: Laemmert \& Co., 1893), $82 \mathrm{n} 1$.

${ }^{46}$ Ibid., 32.
} 
in question. Yet he circumscribed these rights by situating the question of sterilisation solely within the sphere of marriage.

As we will see, he foreshadowed the importance of male control over decisions of reproduction, a position physicians of all kinds would support during eugenic discussions over sterilisation in the 1920s and 1930s. If a married woman had health problems including uterine tumours, cardiac deficiencies or a malformed pelvis - sterilisation, and not a dangerous cesarean section or an embryotomy, was the answer. Why force the couple to engage in contraceptive practices during the act (coitus interruptus), when a simple sterilisation procedure resolved the dilemma? According to Castro, Malthus's dictum of moral restraint was ridiculous. It could even lead to more nefarious sexual practices, including those 'impurities of marriage' alluded to in Madame Bovary (perhaps referencing anal or oral sex). ${ }^{47}$

The decade-long furore exposed the inner workings of a professionalising medical field. Without clear rules and regulations, they would never be taken seriously in the public sphere, and thus effectively respond to societal changes. But the debate was never solely about medical authority, and ideas of heredity, gender and the future of the Brazilian 'race', the underlying currents of these societal changes, underpinned all discussions.

By the late nineteenth century, Brazil's racial makeup, both in terms of phenotype and in terms of overall quality, had taken centre stage in scientific debates over the nation's future. Brazilian legal thinkers and physicians had long debated the racial makeup of the country in relation to phenotype, particularly during the gradual abolition movement of the late nineteenth century. At first, Brazilian positivist intellectuals relied on the theory of scientific racism that had crystallised in the mid to late nineteenth century, when scientists like Herbert Spencer seized upon Darwin's theory of biological evolution and applied it to human societies, naturalising racial hierarchies in scientific terms. ${ }^{48}$ By the century's end, scientific racists across the globe purported a hierarchy of the races based on an 'inherent' white superiority. ${ }^{49}$ The theory also purported that miscegenation, or interracial reproduction, worked against this 'natural' hierarchy and led to degeneration. ${ }^{50}$

But social Darwinism's condemnation of miscegenation contradicted the demographic makeup of the Brazilian population, a country that had forcibly imported nearly five million enslaved Africans. In response, turn-of-the-century Brazilian physicians and jurists adhered to the theory of social evolutionism, which purported that all races were in evolution towards a state of perfectibility. Social evolutionism still reified a racial hierarchy, but it also concluded that miscegenation would help this 'race to the top' as the 'stronger' white race would prevail. ${ }^{51}$

Of course, scientists' ambiguous understanding of heredity meant that degeneration could mean different things to different thinkers, and some thinkers still linked the theory to miscegenation. ${ }^{52}$ For example, the leading republican proponent of degeneration, Raimundo Nina Rodrigues, supported the orthodox social Darwinist belief that racial mixture led to degeneracy. ${ }^{53}$ But Rodrigues was an outlier, and many other Brazilian

${ }^{47}$ Castro, op. cit. (note 45), 62, 66.

${ }^{48}$ Rutledge M. Dennis, 'Social Darwinisim, Scientific Racism, and the Metaphysics of Race', The Journal of Negro Education, 64, 3 (1995), 243-52.

${ }^{49}$ Corrêa, op. cit. (note 20); Schwarcz, op. cit. (note 8); Skidmore, op. cit. (note 8).

${ }^{50}$ Borges, op. cit. (note 10).

51 Schwarcz, op. cit. (note 8), 18, 34-6, 58-60; Skidmore, op. cit. (note 8), 48-69.

52 Borges, op. cit. (note 10); Caponi, op. cit. (note 15).

53 Corrêa, op. cit. (note 20); Schwarcz, op. cit. (note 8), 207-15; Skidmore, op. cit. (note 8), 57-64. 
intellectuals adhered to a different understanding of degenerative thought - that hereditary psychiatric decline occurred in families, not from racial mixture. ${ }^{54}$ Thus, degeneration in Brazil was about more than skin colour. It touched on character, identity and psychology. ${ }^{55}$

Parente's sterilisation practice, and particularly the 1901 trial, directly related to this psychiatric conception of degeneracy, and how it related to medical understandings of the gendered body. Parente had included degeneration as a medical indication in his ads from both 1893 and 1900. His first ad, for example, described sterilisation as necessary 'when it attempts to avoid creating offspring to whom the hereditary transmission of serious illnesses such as syphilis, dementia, epilepsy, cancer, and consumption [tísica] would be inevitable'. ${ }^{56}$ In 1900, he recommended sterilisation for 'degenerate people' (os seres degenerados) ${ }^{57}$ In his 1893 support of Parente, Castro also approached the topic of sterilisation through the lens of degeneration. Castro argued that a married couple who later discovered that one or the other spouse was the carrier of a degenerative defect, including tuberculosis, leprosy, epilepsy or 'madness', should resort to sterilisation to avoid passing the characteristics on to the next generation. ${ }^{58}$

In the 1901 trial, however, the topic of degeneration became even more pronounced when the psychiatrists and obstetricians attacking Parente inverted Castro's reasoning to argue that sterilisation caused degeneration in the female sex. In 1900, one of Parente's patients, Dona Maria Antonieta de Figueiredo Brito, allegedly entered into a psychotic state after submitting to his sterilisation procedure. According to one physician who treated Brito after she fell ill, medico-legal specialist Alfredo do Nascimento, the happily married wife and mother of two children had been healthy until she had undergone fortythree sterilisation treatments at the hands of Parente. Afterwards, Brito entered into a 'complete state of madness' with 'violent' outbursts followed by 'deep' melancholy. ${ }^{59}$ According to Nascimento, Parente had performed his 'secret procedure' without any medical indication, destroying the healthy genitals of a married woman and causing serious mental disturbances. If Parente had evaluated Brito's history, he would have discovered that her parents had had the hereditary defects of tuberculosis and dementia. Here Nascimento implied that sterilisation triggered the 'mental instability' in Brito's family tree.

Nascimento, along with five of his colleagues - including Augusto de Freitas, who specialised in hysteria; Marcio Nery, who worked at the 'Hospício de Alienados' (Lunatic Asylum); Candido de Andrade, who specialised in obstetrics but also worked at the Casa de Saúde Dr. Eiras, where many budding psychiatrists practised; and Fernando Magalhães, the 'father' of Brazilian obstetrics - had examined Brito during her psychosis. ${ }^{60}$ They all concluded that her mental disturbances were directly related to the sterilisation procedure, which had caused 'great deformations' of the cervix and subsequent mental distress. (None considered that the procedure of repeatedly introducing caustic substances into Brito's

\footnotetext{
${ }^{54}$ Borges, op. cit. (note 10), 236-7; Otovo, op. cit. (note 7).

55 Borges, op. cit. (note 10), 235.

56 Abel Parente, 'A minha descoberta de prevenir para sempre a concepção', Gazeta de Noticias, 20 January $1893,2$.

57 'O invento do Dr Abel Parente', O Paiz, 31 December 1900, 2.

58 Castro, op. cit. (note 45), 67.

59 'Denuncia grave', Gazeta de Noticias, 25 November 1900, 2.

60 The information on these physicians comes from the National Academy of Medicine (ANM) website, accessed 10 April 2019, www.anm.org.br/index.asp.
} 
cervix had caused physical anguish.) In light of this medical consensus coming from leading psychiatrists and obstetricians, Nascimento brought the case to the police. ${ }^{61}$

From their mention of her family history, it appears that the psychiatrists, medico-legal specialists and obstetricians debating Brito's case were referring to hereditary psychiatric degeneration not necessarily tied to racial phenotype. Newspaper sources do not mention Brito's race. ${ }^{62}$ We know, however, that the procedure itself cost $\$ 2000000$ milréis. ${ }^{63}$ When compared with the 1903 monthly income of a live-in domestic servant $(\$ 8000$ milréis), we can see that Brito had considerable funds at her disposable to access Parente's services; clearly, this method of sterilisation was out of reach for women of more modest means. ${ }^{64}$ We also know that Brito's husband was related to Nascimento, and that the couple lived in the middle-class Andarahy neighbourhood. ${ }^{65}$ It appears that Brito hailed from the predominantly white upper-middle or upper classes. The fact that she had accessed Parente's services through a newspaper advertisement also hints at her class through her literate status. In a period when the majority of women in the city of Rio de Janeiro were illiterate and public education was nonexistent, Brito most likely came from the privileged classes. ${ }^{66}$ Although physicians never mentioned her race, their reference to her status as a senhora was perhaps a veiled allusion to her lighter skin.

Thus, Brito's degeneration came from her psychiatric background and not necessarily her race. Brito apparently had two hereditary 'defects', loosely defined within scientific understandings of heredity. Her mother had died from tuberculosis, while her father had succumbed to dementia. Despite her father's 'degenerative' disease, Brito had gone through childhood, puberty, marriage and motherhood without showing any abnormal psychological signs. Even attending to her dying father had not 'triggered' this latent defect. Why would it? In doing so, she had fulfilled the nurturing function inherent to her sex. For physicians, it was Parente's unnecessary intervention into Brito's reproductive organs that had prompted her psychosis, as sterilisation contradicted, not supported, a gendered hierarchy. ${ }^{67}$

Scholars have argued that physicians during the Parente affair only discussed population in relation to quantity, contending that sterilisation threatened the Brazilian population's growth. Only with the rise of eugenics in the following decades did the 'social and racial' question come into play regarding reproduction. ${ }^{68}$ Yet the central role that degeneration played as an argument against sterilisation in the Parente question highlights that quality was never absent from Brazilian physicians' discussion of gender, heredity and the Brazilian nation.

61 'O caso Abel Parente', Gazeta de Noticias, 1 December 1900, 1-2.

62 I was unable to find the police investigation and trial in the archives, which perhaps includes more of Brito's identifying information.

63 'O caso Abel Parente', Gazeta de Noticias, 1 December 1900, 1-2.

64 The salary comes from Museu da Justiça, Rio de Janeiro (hereafter MJ), RG.13244 Cx.1403 (1903).

${ }^{65}$ For familial linkages, see 'Denuncia Grave,' Gazeta de Noticias, 25 November 1900, 2. The address was Rua Barão de Mesquita, n 108, 'O caso Abel Parente', Gazeta de Noticias, 8 August 1901, 1. See Republica dos Estados Unidos do Brazil, Recenseamento do Rio de Janeiro em 1906. Estatistica predial e domiciliaria (annexo) (Rio de Janeiro: Officina da Estatistica, 1908), 70-1.

${ }^{66}$ In 1906, 54 per cent of the city's female population was illiterate. Republica dos Estados Unidos do Brazil, Recenseamento do Rio de Janeiro (Districto Federal) (Rio de Janeiro: Officina da Estatistica, 1907), 108-9. On public education, see Jerry Dávila, Diploma of Whiteness: Race and Social Policy in Brazil, 1917-45 (Durham, NC: Duke University Press, 2003).

67 'O caso Abel Parente', Gazeta de Noticias, 1 December 1900, 1-2.

${ }^{68}$ Martins, op. cit. (note 2), 187. 
While in 1893, the police investigation only had advertisements and heated words as evidence, the 1901 trial had the body - and mind - of a woman. In fact, physical evidence proved crucial in advancing the case beyond the investigative phase into a criminal trial. Obstetricians and psychiatrists, outraged at the allegation, provided the forensic exams needed to fulfil the law's burden of proof. The police's psychiatric exam showed that Brito 'was always intelligent, dedicated to her husband, caring for the home'. While she was also 'jealous and nervous', she had never been hysterical. ${ }^{69}$ With Brito, instead of preventing degeneration, sterilisation had caused it! Physicians had naturalised motherhood within the biological female body, itself the foundation of the nuclear family, based on a man's patriarchal prerogative over his wife, whose motherhood was her only purpose. ${ }^{70}$ This gendered order of things was, of course, the basis of the Brazilian nation. ${ }^{71}$ Sterilisation thus directly threatened its future. Changing women's biological functions, which then affected their 'natural' maternal nature, led to degeneration. 'Respectable' women like senhora Brito were exactly the demographic these physicians wanted to reproduce. Although they did not support sterilisation for any women - regardless of race - they particularly could not support it for women they believed would birth a modern Brazil. During the Parente affair, sterilisation was part of what Western physicians saw as civilisation's degenerative effects on the female sex. ${ }^{72}$ The rise of the 'modern woman', who went out with friends, worked for wages and perhaps avoided pregnancy, was a grave threat to patriarchal power - of individual men and of male leaders. ${ }^{73}$ Part of the problem with civilisation, in this view, was that it allowed women to negate their natural duty: motherhood.

As a result of the investigation, Parente went before a special correctional board, which found him guilty of Article 306 of the 1890 Penal Code (physical harm done to a third person in the practice of one's profession) and condemned him to the minimum sentence of fifteen days in prison. ${ }^{74}$ Parente immediately appealed, however, and was acquitted on a legal technicality. ${ }^{75}$

Throughout the entire Parente affair, physicians debated the boundaries of their profession to consolidate their social and political authority on gender in the public sphere. The alleged psychotic episode of his female patient, Brito, demonstrated why this authority had to be unified and assertive. The future of the Brazilian nation was at stake, and threats to traditional gender roles could cause unforeseen consequences.

Physicians and jurists were not the only ones to weigh in on the Parente debate; the religious press also made claims. When Parente first advertised his sterilisation technique in the early 1890s, Rio de Janeiro's Catholic newspaper, O Apostolo condemned the

69 'Caso Abel Parente', Gazeta de Noticias, 10 February 1901, 2.

${ }^{70}$ See Martins, op. cit. (note 2); Londa Schiebinger, Nature's Body: Gender and the Making of Modern Science (Rutgers, NJ: Rutgers University Press, 2004).

71 See 'A abandonada', Gazeta de Noticias, 9 April 1901, 1; Bulhões Carvalho, 'O invento Abel Parente', Revista do Instituto da Ordem dos Advogados Brazileiros 14 (June 1893), 190. See also Martins, op. cit. (note 2), 185.

72 See José de Paula Camara, Do aborto criminoso (Rio de Janeiro: Typographia Montenegro, 1898), 11-12.

73 On the 'modern woman', see Martha de Abreu Esteves, Meninas perdidas: os populares e o cotidiano do amor no Rio de Janeiro da Belle Époque (Rio de Janeiro: Paz e Terra, 1989); Besse, op. cit. (note 17); Sueann Caulfield, In Defense of Honor: Sexual Morality, Modernity, and Nation in Early-Twentieth Century Brazil (Durham, NC: Duke University Press, 2000).

74 João Vieira de Araujo, O Codigo Penal interpretado, vol. 2 (Rio de Janeiro: Imprensa Nacional, 1902), 40-54.

75 'O caso Abel Parente', Gazeta de Noticias, 7 August 1901, 2; 'O caso Abel Parente', Gazeta de Noticias, 8 August 1901, 1; 'Julga-se hoje', Gazeta de Noticias, 30 October 1901, 1; 'O caso Abel Parente', Gazeta de Noticias, 31 October 1901, 2. 
procedure as 'immoral and scandalous'. ${ }^{76}$ Similar to physicians' views, and in line with church doctrine, the Catholic press viewed the separation of sexual intercourse and reproduction as a direct threat to the family. In an article decrying the Brazilian congress's debate of a proposed civil divorce law in 1893, for example, the paper argued that divorce would 'complete that which the Abel Parente method has not achieved' ${ }^{77}$ The church saw reproduction as its sphere of authority, and one it did not want to cede to the medical profession, or the legislators of a secular state. ${ }^{78}$ Nevertheless, their positions were similar to those of the medical community. Even Francisco de Castro saw no contradiction between his support for sterilisation in limited cases and his religious ideals. For Castro, women's role was to procreate, as God demanded. Man was there to help this natural order of things progress smoothly: 'The Lord commanded and nature commands that we populate the earth ... [but] we should smother in its breast the seeds of pernicious and devastating renovation. ${ }^{79}$

Leading physicians and jurists also argued that Parente's practice of sterilisation allowed women (of the upper classes) to access his services individually, threatening husbands' or fathers' individual patriarchal prerogative. In the 1901 case, physicians were outraged that Parente had treated Brito without her husband's consent. The Italian physician had sterilised Brito 'without even hearing or in any way consulting with her husband' ${ }^{80}$ Parente's individual practice was creating space for upper-class women - as mothers and wives, maidens and widows - to break free from their 'natural' gender roles. According to the lawyer Evaristo de Moraes, Parente's invention erased 'the great danger that exists for young maidens [donzelas] that want to appear as such, or for the modest widows who are not; the great danger that is the result of a mistake, the revelation of an error, conception, a child! ${ }^{81}$ In other words, sterilisation allowed women to have sex without the consequence of getting pregnant, giving them, and not men, power over their bodies and sexuality.

To some extent, these physicians were correct. According to the physician, Brito had learned of Parente through another senhora, who had accompanied her to the treatments. ${ }^{82}$ Other female patients of Parente published letters of support in the papers. ${ }^{83}$ In a protest that various medical students staged against Parente after his acquittal, the press reported two senhoras, 'one of whom ... [was] in tears, asking that nothing be initiated against Dr. Abel Parente'. ${ }^{84}$ To the journalists reporting the story, these women were clearly invested in controlling their fertility and did not want their husbands, priests or other physicians interfering. For those literate, upper-class women who could afford Parente's services, sterilisation represented an opportunity to control their reproductive lives.

In a larger sense, the Parente case represented how the country's leaders viewed femaledecided fertility control as an attack on the medical profession. As Moraes argued, Parente had corrupted 'not only society ... not only the domestic sphere ... [but also] the studied youth ... the honour of Brazilian medicine'. ${ }^{85}$ In a moment when state institutions,

\footnotetext{
76 'Invento Abel Parente', O Apostolo, 15 February 1893, 2.

77 'Os demolidores brasileiros', O Apostolo, 21 June 1893, 2.

78 Stepan, op. cit. (note 13), 111.

${ }^{79}$ Castro, op. cit. (note 45), 69.

80 'Denuncia grave', Gazeta de Noticias, 25 November 1900, 2.

81 'O caso Abel Parente', Gazeta de Noticias, 8 August 1901, 1.

82 'O caso Abel Parente', Gazeta de Noticias, 1 December 1900, 1-2.

83 'Acha-se exposto', O Paiz, 6 January 1892, 2; 'Gratidão', O Paiz, 10 March 1893, 3.

84 'Manifestação Abel Parente', Gazeta de Noticias, 5 May 1901, 2.

85 'O caso Abel Parente', Gazeta de Noticias, 8 August 1901, 1.
} 
including public health agencies and the criminal justice system, were working to control the Brazilian body politic through the reinforcement of traditional gender norms, femaledecided sterilisation - representing female autonomy and a break between sexuality and marriage and procreation - posed a grave threat not only individual patriarchs but also to medical authority in general. ${ }^{86}$ Physicians should be working with patriarchs to shore up a gendered hierarchy, not against them. ${ }^{87}$ As the case of Brito made scientifically clear, these threats were not merely symbolic. Rather, rejecting the gendered order of things led to severe medical and societal consequences.

\section{Sterilisation, Eugenics and Degeneracy}

While Parente stopped advertising his sterilisation services after the 1901 trial, debates over degeneration, reproduction and racial fitness continued in the halls of medicine, the columns of newspapers and the whispers of women across the city. In the following decade, several medical students tried to publish theses in the field of legal medicine on female sterilisation, supporting Parente's practice and methods; however, the medical school rejected the submissions. ${ }^{88}$ Despite this internal policing, Parente's advertisements opened up a new space for some physicians and midwives to publicise their contraceptive and abortion techniques in the city's newspapers. ${ }^{89}$ It seems that the profession's worst fears had come true. ${ }^{90}$ By advertising a questionable practice without first discussing it within the established medical profession, Parente had created a public space in which women of means could independently access sterilisation and even abortion services.

But medical debates over sterilisation underwent profound changes with the arrival of eugenics in the late 1910s. Obstetricians and psychiatrists, once united in their rejection of female sterilisation, diverged in their thinking in the following decades. Brazilian eugenicists mainly followed a neo-Lamarckian understanding of heredity, situating it within both biological and social explanations and emphasising the role of hygiene and education in changing a population's genetic makeup. ${ }^{91}$ This stood in contrast with the Mendelian genetics that characterised US and German thought, which separated heredity from environmental influences. ${ }^{92}$ While the Brazilian eugenics movement was never quite that clear-cut - the scientific community participated in lively debates about neo-Lamarckian versus Mendelian eugenics, and adherents to Mendel's theory became leading eugenicists - the neo-Lamarckian version held out until the 'evolutionary

\footnotetext{
${ }^{86}$ On gender and the criminal justice system, see Sueann Caulfield, 'Getting into Trouble: Dishonest Women, Modern Girls, and Women-Men in the Conceptual Language of "Vida Policial”, 1925-1927', Signs, 19, 1 (1993), 146-76; Cassia Roth, 'Policing Pregnancy: Reproduction, Poverty, and the Law in Early Twentieth-Century Rio de Janeiro', Journal of Women's History, 29, 4 (2017), 85-108.

87 'A abandonada', Gazeta de Noticias, 9 April 1901, 1.

${ }^{88}$ Martins, op. cit. (note 2), 186; Rohden, op. cit. (note 2), 204-14.

89 See 'Dr. Baptista dos Santos, parteiro', O Paiz, 16 July 1902, 4; 'Dra. Parteira Maria Preciosa Pinto', Jornal do Brasil, 27 October 1907, 13.

${ }^{90}$ Manoel Mendes Campos, Aborto criminoso (Rio de Janeiro: Commercio de Rodrigues, 1911); Archmimo Martins de Mattos, Aborto criminoso (Rio de Janeiro: Commercio de Rodrigues, 1923); Aristides Teixeira de Rezende, Considerações em torno do aborto (Rio de Janeiro: Graphicos Bloch, 1930); Mileto Rizzo, Considerações acerca do aborto criminoso (Rio de Janeiro: Metropole, 1926).

91 Stepan, op. cit. (note 13), 67-95.

92 Daniel J. Kevles, In the Name of Eugenics: Genetics and the Uses of Human Heredity, New Preface (Cambridge, MA: Harvard University Press, 1995).
} 
synthesis' of Mendelian genetics with Darwinism in the 1940 s. $^{93}$ In the early 1920 s, however, most Brazilian eugenicists accepted positive social engineering practices, such hygienic education, rather than negative sterilisation measures common to Mendelianbased eugenics. ${ }^{94}$

This was especially true for the obstetricians, gynaecologists and paediatricians leading the country's growing maternal-infant health movement in the $1920 \mathrm{~s} .{ }^{95}$ Most obstetricians involved with eugenics, including Fernando Magalhães, associated themselves with the neo-Lamarckian-based preventive or 'positive' form of eugenics. ${ }^{96}$ The former worked to improve the health and social hygiene of the population at large and the latter towards incentivising the reproduction of 'superior' individuals. ${ }^{97}$ As Magalhães wrote in the Catholic newspaper A Ordem in 1929, 'It is well known how misery and disease are anti-eugenic factors, but if the problem includes economics, health, and offspring, why do we resolve this with the right to sacrifice the offspring without the duty to attend to the economy and the health of each one?' 98 In this way, the majority of obstetricians and gynaecologists continued condemning sterilisation. ${ }^{99}$ Nevertheless, the idea that sterilisation caused degeneration disappeared from the writings of women's health practitioners. To be clear, obstetricians and gynaecologists continued to connect women's reproductive functions to their mental health, but they no longer purported that sterilisation led to degeneration. ${ }^{100}$ As we will see, changes in clinical practice influenced this shift.

For Magalhães, a devout Catholic, neo-Lamarckian eugenics also allowed him to reconcile his professional authority with his religious beliefs. Magalhães's publication in a Catholic newspaper highlights the resurgence of Catholic activism in the 1920s and its influence on physicians. As the Brazilian Catholic church put renewed effort towards influencing the political realm through the creation of lay religious groups, Catholic thinkers re-asserted their public presence in gendered debates. The Centro Dom Vital, opened in 1922, and the publication A Ordem (first published in 1921) created an intellectual space for Catholic thinkers - secular and religious alike - to debate matters of the family, including eugenics and sterilisation. ${ }^{101}$ Catholic physicians began proclaiming their Catholic faith as an integral component of their professional identity, demonstrating both the revitalised importance of Catholic organising and the strong position of a professional medical identity separate from religion.

93 Borges, op. cit. (note 10), 251; Souza, op. cit. (note 15); Stepan, op. cit. (note 13), 95-100; Wegner and Souza, op. cit. (note 15).

94 Stepan, op. cit. (note 13), 73.

95 Besse, op. cit. (note 17); Maria Martha de Luna Freire, Mulheres, mães e médicos: discurso maternalista no Brasil (Rio de Janeiro: Editora Fundação Getúlio Vargas, 2009); Ana Paula Vosne Martins, " "Vamos criar seu filho": os médicos puericultores e a pedagogia materna no século XX', História, Ciências, Saúde-Manguinhos, 15, 1 (2008), 135-54; Otovo, op. cit. (note 2).

96 Vanderlei Sebastião de Souza, 'Por uma nação eugênica: higiene, raça e identidade nacional no movimento eugênico brasileiro dos anos 1910 e 1920', Revista Brasileira de História da Ciência, 1, 2 (2008), 146-66.

97 Wegner and Souza, op. cit. (note 15), 265.

98 Fernando Magalhães, 'Maternidade consciente', A Ordem, 2, 3 (1929), 191.

${ }^{99}$ See Luiz Gonzaga Vianna Barbosa, Malthus no Brasil (Rio de Janeiro: Papelaria Sol, 1911), 54-62; João Costa, A restricção da natalidade (Rio de Janeiro, 1913), 29.

100 Alipio Azevedo, Das physchoses puerperaes e suas relações com os processos auto-toxios (Rio de Janeiro: Pap. Confiança, 1919); Aderval da França Gomes, Psychoses puerperaes (Rio de Janeiro: Papelaria Mello, 1927); Henrique Post, Psychoses do post partum (Rio de Janeiro: Typographia Coelho, 1925).

101 On the resurgence of Catholic intellectual activism, see Sergio Miceli, Intelectuais à brasileira (São Paulo: Companhia das Letras, 2001), 127-31. 
While the majority of obstetricians supported preventive eugenics, other medical fields espoused the dangers of degeneration related to both psychiatry and race. Psychiatrists, many of whom dominated eugenic circles, began diverging from their turn-of-thecentury psychiatric colleagues. Beginning in the late 1910s, psychiatrists began supporting sterilisation. Historians have demonstrated how in the late 1920s and early 1930s, a period when some Brazilian eugenicists held an affinity towards US and German policies, degeneration in all its forms found fertile ground. ${ }^{102}$ They have pinpointed that a shift occurred when the country's leading eugenicist, the psychiatrist Renato Kehl, started working for the German multinational Bayer in Rio de Janeiro in 1927. As part of his work, Kehl took various trips to Germany, Sweden and Norway and integrated himself into the eugenic discussions occurring there and in the US. ${ }^{103}$ In the early 1930s, Kehl began proposing a more negative form of the 'science', defending the compulsory sterilisation of criminals, the mentally ill and the catch-all phrase 'degenerates' while also condemning racial mixture. ${ }^{104}$ Other eugenicists, mainly his psychiatric colleagues, supported his racist and interventionist proposals. ${ }^{105}$ Kehl argued for both psychiatric and racial degeneration and believed that sterilising both genders would solve both problems. The late nineteenthcentury psychiatric aspect of degenerative thought had survived the end of scientific racism to crystallise in new forms during the eugenics movement. ${ }^{106}$

Yet psychiatrists, including Kehl, had discussed sterilisation of 'abnormal' citizens from the early 1920s. In 1921, for example, one psychiatric medical student published a dissertation in which he quoted Kehl, arguing for the sterilisation of 'abnormals' as a 'eugenic method'. He clarified, moreover, that sterilisation was a preventative measure without any risks: 'The sterilisation of abnormals is not, thus, a method with the tendency of disrupting the functions of healthy individuals. ${ }^{, 107}$ In 1930, another medical student specialising in hygiene argued in a similar vein: 'We are of the opinion that sterilisation is indicated in special cases of disease and misery; that it should be applied compulsorily to certain criminals and in certain cases of psycho-somatic degeneracy.' ${ }^{108}$ Although both physicians spoke in gender neutral terms, it appears they rejected the idea that sterilisation would permanently alter a woman's mental state. Part of this shift was due to better scientific understandings of heredity. A single degenerative 'trait' no longer existed, and a procedure could not trigger it.

At the same time, Kehl also shifted away from his earlier neo-Lamarckian views to embrace Mendelian genetics. ${ }^{109}$ By the late 1920s, Mendelian eugenicists in Brazil no longer argued that 'degeneration' was a single acquired trait that could be inherited; rather,

\footnotetext{
102 On degeneration, see Borges, op. cit. (note 10), 255-6; Caponi, op. cit. (note 15), 162-3, 167-8, 175. On negative Mendelian eugenics, see Souza, op. cit. (note 15).

${ }^{103}$ Marlom Silva Rolim and Magali Romero Sá, 'A política de difusão do germanismo por intermédio dos periódicos da Bayer: a Revista Terapêutica e O Farmacêutico Brasileiro', História, Ciências, Saúde Manguinhos, 20, 1 (2013), 173-6.

104 Caponi, op. cit. (note 15), 167; Souza, op. cit. (note 15), 96-7, 100-1; Wegner and Souza, op. cit. (note 15), 264, 268.

105 Caponi, op. cit. (note 15), 172; Wegner and Souza, op. cit. (note 15), 271.

106 Borges, op. cit. (note 10), 240-1; Corrêa, op. cit. (note 20), 68.

107 Manoel Tavares Neves Filho, Da esterilisação de anormaes como factor eugenico (Rio de Janeiro: Pap. Confiança, 1921), 50.

108 Manoel Ligiéro, Algumas considerações sobre o néo-malthusianismo como factor eugenico (Rio de Janeiro: Typ. Yankee, 1930), 49.

109 Souza, op. cit. (note 15), 98.
} 
heredity was a more complex genetic process. ${ }^{110}$ But, as historian Vanderlei Sebastião de Souza has argued, it was not Kehl's Mendelian turn but his association with racist thinkers in Europe and the US that influenced his embrace of sterilisation. Another leading eugenicist, the anthropologist Edgard Roquette-Pinto, also adhered to Mendelian genetics but rejected compulsory sterilisation and racial segregation. ${ }^{111}$ The continued debates between the anti-racist theories of thinkers from both sides ameliorated Kehl's power within the movement, and he served as only one voice in a cacophony of theories on the future of the Brazilian population. ${ }^{112}$

While scholars have deftly analysed the intricacies of the eugenics movement in the 1910s, 1920s and 1930s, they have overlooked how obstetricians and gynaecologists the physicians who would have practised sterilisation techniques or advised mothers on infant hygiene - debated these shifts. ${ }^{113}$ Obstetricians' and gynaecologists' longstanding rejection of sterilisation meant that when psychiatrists brought up these ideas in the late 1920s to mid-1930s, most women's health practitioners disagreed with negative measures and refused to support the policy. Like psychiatrists, obstetricians moved away from viewing sterilisation as the cause of degeneration, but they also rejected it as a eugenic method.

The country's first national eugenics conference in 1929 is one example. Most participants supported psychiatrist Alberto Farani's declaration that vasectomy and tubal ligations [ressecção tubaria] were 'benign', and that the sterilisation of 'degenerates' was 'legitimate' within 'neuro-psychiatric indications'. ${ }^{114}$ It appears that sterilisation in relation to psychiatric indications had become established eugenic thought. But obstetricians like Fernando Magalhães also presented an anti-racist position in relation to the population, excluding mixed-race individuals from psychiatric definitions of degeneracy. 'Eugenics does not exclude mankind', Magalhães told the conference participants. ${ }^{115}$ 'P] $\mathrm{P}$ igment does not exclude quality. There is an injustice because our entire past was based on the mestiço, because we are all mestiços' ${ }^{116}$ Changing gender roles were just as, if not more, dangerous than racial mixing. Magalhães said as much when he warned participants that feminism was the true 'danger that threatened the race'. ${ }^{117}$

A 1934 debate between eugenicists printed in the Rio de Janeiro newspaper $O$ Globo demonstrates that sterilisation continued to occupy a central role in eugenic thinking in the years following the conference. In it, eugenicists discussed Nazi Germany's recent sterilisation law and debated whether the Brazilian legislature should do the same. Mainly psychiatrists, but also leading eugenicists from other branches of medicine, deliberated sterilisation from both Mendelian and Lamarckian perspectives, with pro- and antisterilisation physicians arguing from both sides. Psychiatrists, including Kehl, contended

110 Neves Filho, op. cit. (note 107).

111 Souza, op. cit. (note 15). For example, Edgard Roquette-Pinto, 'Devem ser esterilizados os enfermos incuráveis?', $O$ Globo, 2 January 1934, 1.

112 Souza, op. cit. (note 15); Stepan, op. cit. (note 13), 157-62.

113 Parts of the following discussion are based on Roth, op. cit. (note 2), 17-19, 49-52.

114 On the proposal, see Alberto Farani, 'Acta da setima reunião', in 1 Congresso Brasileiro de Eugênia: actas e trabalhos, vol. 1 (Rio de Janeiro, 1929), 38.

115 Fernando Magalhães, 'Acta da segunda reunião', in 1 Congresso Brasileiro de Eugênia: actas e trabalhos, vol. 1 (Rio de Janeiro, 1929), 20

116 Ibid., 20.

117 Magalhães, 'Acta da oitava [sic] reunião', in 1 Congresso Brasileiro de Eugênia: actas e trabalhos, vol. 1 (Rio de Janeiro, 1929), 24. This paragraph is from Roth, op. cit. (note. 2), 51. 
that sterilisation laws were necessary to stop degenerative individuals from reproducing. ${ }^{18}$ Others, including anthropologist Roquette-Pinto, believed that it opened the door for abuses. ${ }^{119}$

The debate, nevertheless, was not about the clinical practice of individual physicians (as had been the case with the Parente affair). By this time, physicians were ensconced in the public sphere. Rather, eugenicists were discussing the parameters of medical and state policy, which they viewed as one and the same. As the psychiatrist Antônio Carlos Pacheco e Silva wrote, 'all of these cases, nevertheless, are of the elevation of the physician, within whose criteria rests the need of intervening or not' ${ }^{120}$ In fact, the firm political position of medicine meant that Catholic physicians used religious arguments in their favour. Surgeon Augusto Paulino reminded physicians of 'the value of Catholic moral education', concluding that 'science tells us what can be and morality what should be'. ${ }^{121}$

Nor was the debate focused on whether sterilisation caused degeneration. In fact, the physicians were no longer only discussing interventions into the female body. Raul Leitão da Cunha, a specialist in anatomy who supported limited sterilisation, argued that it could not be utilized with men because, among them, heterosexual attraction guaranties procreation, and it is not exclusively instinctive'. ${ }^{122}$ Pacheco e Silva outlined that vasectomies for men and tubal ligation (ligadura das trompas) for women were the safest and easiest methods, and he outlined many more female 'conditions' that called for sterilisation, including puerperal psychosis. ${ }^{123}$ In a reverse of previous psychiatric thought, sterilisation could prevent psychosis, not cause it.

The $O$ Globo debate over heredity, eugenics and sterilisation also occurred within a different political landscape. The arrival of Getúlio Vargas to the presidency in 1930, and his increasingly authoritarian tendencies throughout the decade, resulted in two somewhat contradictory developments in state policy towards reproduction. On the one hand, Vargas allied himself with the growing resurgence of Catholic activism in the country to forge a new church-state alliance. In the 1930s, under influence from Vatican doctrine, the Brazilian church centralised the extra-hierarchical activities of the Centro Dom Vital to further influence the political realm, which resulted in the incorporation of Catholic tenets, such as prohibition on divorce, into the 1934 Constitution. ${ }^{124}$ The 1930 papal bull Casti connubii also shaped the Brazilian church's intellectual approach towards reproduction, as it declared an official church ban on eugenics, sterilisation and artificial forms of birth control. As they courted the Vargas administration, both the Vatican and the Brazilian church rejected women's contraceptive use and the medical profession's interference in the realm of the family. ${ }^{125}$ Perhaps it is not surprising that Kehl and other eugenicists who supported sterilisation rejected Catholic arguments and viewed the Church as the main impediment to implementing sterilisation programmes. ${ }^{126}$

\footnotetext{
${ }^{118}$ Renato Kehl, 'Devem ser esterilizados os enfermos incuráveis?', O Globo, 3 January 1934, 1; Antônio Carlos Pacheco e Silva, 'Devem ser esterilizados os enfermos incuráveis?', O Globo, 13 January 1934, 2.

119 Edgar Roquette-Pinto, op. cit. (note 111), 1; Augusto Paulino, 'Devem ser esterilizados os enfermos incuráveis?', O Globo, 15 January 1934, 1.

${ }^{120}$ Pacheco e Silva, op. cit. (note 117), 2.

121 Paulino, op. cit. (note 118), 1.

122 Raul Leitão da Cunha, 'Devem ser esterilizados os enfermos incuráveis?', O Globo, 5 January 1934, 1.

123 Pacheco e Silva, op. cit. (note 117), 2.

124 Miceli, op. cit. (note 101), 129-31.

125 Stepan, op. cit. (note 13), 111-12.

${ }^{126}$ Wegner and Souza, op. cit. (note 15), 273-4, 282-4.
} 
At the same time that negative eugenics hit a barrier in the renewed alliance between church and state, a new 'culturalist' racial paradigm entered the scene to further weaken psychiatrists' ability to implement negative eugenic measures based on phenotype. ${ }^{127}$ Intellectuals and policymakers across the disciplinary spectrum believed that the Brazilian population was, in fact, whitening itself. Social scientists began discussing Brazil's racial future in cultural and not scientific terms, celebrating racial mixing and incorporating Afro-descended cultures into a new 'Brazilian' national identity. ${ }^{128}$ Vargas's authoritarian dictatorship (the Estado Novo, 1937-45) adopted these new cultural understandings of racial harmony, supporting mestiçagem not because it whitened the population but because it created a new Brazilian citizen. However, the idea of 'racial democracy', as it came to be known, never rejected the underlying belief that racial mixing and harmony would whiten the population. ${ }^{129}$ And while racial democracy shifted mentions of race from biology to culture, eugenicists continued to imbue this new cultural rhetoric with biological connotations based on racial hierarchies. ${ }^{130}$

The strengthening of a church-state alliance and the arrival of new cultural discussions of racial mixing did not mean that Vargas rejected eugenics full stop. Vargas's centralisation and expansion of the federal government extended state power to control and manage what elites viewed as 'dangerous' groups. That is, the government focused its burgeoning welfare-state efforts on the populations that psychiatrists had long debated the 'degenerates' - but state policies did not include forced sterilisation. ${ }^{131}$ Moreover, the 1934 constitution, while upholding religious ideals, still included the provision of eugenic education and prenuptial exams into its text, demonstrating its political legitimacy. ${ }^{132}$

\section{Safe and Painless: The Clinical Practice of Female Sterilisation}

In the 1934 O Globo debate, opposing physicians may have differed on the appropriate use of sterilisation techniques, but they all agreed that medical advancements had ensured that sterilisation techniques were now safe, easy and painless. ${ }^{133}$ This assertion was also a marked difference from the Parente debates when, as we saw, surgical techniques in relation to permanent sterilisation were rudimentary and often dangerous. Tubal ligations - the technique the $O$ Globo debate foregrounded - remained uncommon until the early twentieth century. As we saw, nineteenth-century physicians initially experimented with cauterising or tying the Fallopian tubes after a cesarean section through the abdominal cavity. In the early twentieth century, Western physicians began employing transcervical methods, and by 1920 German gynaecologists and obstetricians had advanced the ligation (tying) technique. ${ }^{134}$ In the 1920 s and 1930s, women's health physicians in the US and Europe attempted other forms of tubal ligation, including transcervical

\footnotetext{
${ }^{127}$ Micol Seigel, Uneven Encounters: Making Race and Nation in Brazil and the United States (Durham, NC: Duke University Press, 2009), 195

128 Borges, op. cit. (note 10), 253; Paulina L. Alberto, Terms of Inclusion: Black Intellectuals in TwentiethCentury Brazil (Chapel Hill: University of North Carolina Press, 2011), 178-81.

129 Alberto, Ibid.; Seigel, op. cit. (note 126), 128-35, 195.

130 Corrêa, op. cit. (note 20), 203-4; Schwarcz, op. cit. (note 8), 172, 248.

131 Borges, op. cit. (note 10), 256; Stepan, op. cit. (note 13), 162-9.

132 Stepan, op. cit. (note 13), 126.

133 Kehl, op. cit. (note 117), 1. See also Wegner and Souza, op. cit. (note 15), 277.

${ }^{134}$ Dowbiggin, op. cit. (note 27), 23.
} 
electro-cauterisation. ${ }^{135}$ Obstetricians and gynaecologists also developed a hysteroscope or an endoscope to visualise the uterine cavity, aiding transcervical methods. But until as late as the mid-century, Western medicine considered hysterectomy the safest permanent method of sterilisation, followed by tubal ligations via abdominal surgery. ${ }^{136}$

It appears that Brazilian physicians' claims of sterilisation's safety were misguided. Female sterilisation procedures, in particular, were dangerous. Despite advances in transcervical methods, Brazilian gynaecologists and obstetricians most often practised them after an abdominal incision, and in the pre-antibiotic era, any surgery was risky. In fact, physicians' statements were more indicative of furthering their medical authority than clinical realities. The Catholic politician Hamilton Nogueira said as much in his refutation of eugenic sterilisation in 1932: 'If the vasectomy, for example, is a simple operation, the same cannot be said' of female sterilisation after an abdominal incision. ${ }^{137}$

Exploring when and for what reasons obstetricians sterilised their patients highlights that, although medical advances had occurred since Parente's trial, female sterilisation procedures could be anything but safe, easy and painless. Clinical records from Rio de Janeiro's main public maternity and teaching hospital Maternidade Laranjeiras from the 1920s demonstrate that obstetricians performed tubal ligations and hysterectomies via the abdomen - but only after cesarean sections. In June 1924, for example, a branca (white) twenty-three-year-old woman was admitted to the hospital in labour. The attending physician, Octávio de Souza, performed a cesarean due to the woman's deep lumbar curve. Souza successfully delivered twins and, before suturing the abdomen, executed a 'tubal castration'. ${ }^{138}$ In September of that same year, Souza once again performed a tubal ligation after a cesarean. His patient, a thirty-eight-year-old parda (mixed-race) woman, had already delivered twice by cesarean. After delivering a premature boy, he performed a bi-lateral tubal castration. ${ }^{139}$

Obstetricians also used hysterectomies to sterilise their female patients. In June 1924, Magalhães performed a cesarean section and hysterectomy on his twenty-seven-year-old primigesta preta (black) patient. Magalhães cited a malformed pelvis as the reason behind the surgery. Both mother and infant survived. ${ }^{140}$ The following year, another obstetrician, Oliveira Mello, delivered a stillborn infant after which he performed a hysterectomy on his forty-year-old branca patient. The woman survived, although after suffering from infection. ${ }^{141}$ Obstetricians also performed hysterectomies after infected miscarriages or placental abruptions, but in three of the hospital's four cases between 1923 and 1925, the women died. ${ }^{142}$

\footnotetext{
135 Sabine Hildebrandt et al., "Forgotten" Chapters in the History of Transcervical Sterilization: Carl Clauberg and Hans-Joachim Lindemann', Journal of the History of Medicine and the Allied Sciences, 72, 3 (2017), 277.

136 Ibid., 276-8.

${ }^{137}$ Hamilton Nogueira, 'Esterilisação dos inaptos', A Ordem, 7, 32 (1932), 257.

138 Octacilio Rolindo, 'Registo da clinica obstetrica de junho 1924', Revista de Gynecologia e D'Obstetricia, 18, 7 (1924), 262-3, patient 20172.

139 Octacilio Rolindo, 'Registo da clinica obstetrica de setembro 1924', Revista de Gynecologia e D'Obstetricia, 18, 10 (1924): 380-1, patient 20476.

${ }^{140}$ Ibid., 256, patient 20068.

141 Octacilio Rolindo, 'Registo da clinica obstetrica de abril 1925', Revista de Gynecologia e D'Obstetricia, 19, 5 (1925), 184, patient 21231.

${ }^{142}$ For the patients who died, see Octacilio Rolindo, 'Registo da clinica obstetrica de novembro 1923', Revista de Gynecologia e D'Obstetricia, 17, 12 (1923), 515, patient 19488; Rolindo, op. cit. (note 138), 376-7, patient 20400; Rolindo, 'Registo da clinica obstetrica de dezembro 1924', Revista de Gynecologia e D'Obstetricia, 19, 1 (1925), 21-2, patient 20011. For the patient who survived, see Rolindo, op. cit. (note 138), 381-2, patient 20476.
} 
These surgeries most likely occurred under anaesthesia, yet the brief clinical notes include no mention of consent, and the physicians never justified the procedures. Were obstetricians sterilising women because they believed another pregnancy would lead to maternal death? The surgeries were probably crucial in saving these women's lives, but they could also prove deadly. Thus, while obstetricians rejected sterilisation for eugenic reasons, or women's own desire to not bear more (or any) children, they found no qualms performing procedures themselves. These were not rogue physicians providing services to women outside the watchful eye of clinical medicine. They were the men establishing the parameters of best practice. And from the patients' various races, it appears that obstetricians were not discriminating on race, a practice in line with their theoretical support of racial mixing. Their practice further highlights obstetricians' turn away from the idea that sterilisation caused female degeneration. If this were the case, then no one, not even a trained obstetrician, should perform the procedure. By disconnecting sterilisation from degeneracy, obstetricians created a legitimate medical space for them, and only them, to employ the procedure.

As established obstetrics incorporated permanent sterilisation into their repertoire of treatments, one in which women patients themselves had no say, they pushed unauthorised and unsanctioned techniques into the hands of those practising outside medicine's legal parameters, most often semi-trained but unlicenced midwives. In 1937, for example, the Rio de Janeiro police received a tip that the midwife Odilia Ferreira Villela was 'prescribing drugs and other medications against procreation'. ${ }^{143}$ In their raid, investigators found Villela after she had 'just finished performing an injection on a patient so that she did not become pregnant'. Her patient, the twenty-one-year-old married Cecilia Azevedo, testified that she frequented Villela's midwifery clinic on a monthly basis to receive 'treatments to avoid pregnancy'. Azevedo already had a one-year-old child, but she suffered during her pregnancies and 'for that reason' she underwent monthly sterilisation treatments. For a fee, Villela injected substances into or cauterised Azevedo's uterus, although both midwife and patient were equally unclear in their description of the procedure. It appears, however, that Villela's treatments mirrored those of Parente from forty years earlier. Villela, for her part, denied the allegation, stating that she 'never sought to practice treatments ... to avoid pregnancy'. Possibly due to what Villela described as an 'eroded cervix', perhaps from the treatments themselves, Azevedo had not become pregnant since she had started seeing the midwife a year earlier.

Later that year, the same team of investigators raided the midwifery clinic of Maria Berlimont after receiving a denunciation that Berlimont was practising 'deliveries, abortions, and other gynaecological treatments'. ${ }^{144}$ Three women were waiting for Berlimont's services when the police arrived. When questioned, thirty-three-year-old married Maria de Carvalho declared that this was her second visit to Berlimont's clinic to receive treatments 'to avoid procreation'. Another patient, twenty-four-year-old married Herondina Dias, told the police that Berlimont had attended the birth of her first child, and now she was receiving treatments for a 'wound on her uterus'. Aurora Moreira da Rocha, a twenty-nine-year-old married woman, 'knowing that the senhora Berlimont performed treatments to avoid procreation', was also waiting for her monthly visit.

These police investigations demonstrate that physicians' early twentieth-century fears that middle- or upper-class married women were accessing contraceptive services outside

143 Arquivo Nacional, Rio de Janeiro (hereafter AN), 6Z.0.PCR.20528 (1937).

144 AN, CT, Cx.1830 N.1386 (1937). 
the realm of patriarchal authority was still true in the 1930s. Just as Maria Antonieta de Figueiredo Brito allegedly had resorted to Parente's sterilisation services without her husband's knowledge in 1900, so too did the women at Villela's clinic. In the raids, all the female patients were married, and many already had at least one child. Not one mentioned their husbands when they discussed wanting to prevent a future pregnancy. These were senhoras through and through - the exact women that physicians wanted procreating the Brazilian nation. If neither marriage, motherhood nor medicine could contain the aberrant female body, then what could?

\section{Conclusion}

The topic of female sterilisation came to the fore at various moments in early twentieth-century Rio de Janeiro, Brazil. Physicians debated the practice in relation to changing understandings of race, gender and heredity, using the dispute to consolidate their profession in the public sphere. Many turn-of-the-century medical practitioners, particularly psychiatrists and obstetricians, viewed sterilisation as causing degeneracy in the female sex. This understanding was both literal - intervening in women's healthy reproductive organs caused psychosis - and figurative, as sterilisation caused the dissolution of the family, the building block of a strong social order. At the same time, degeneracy itself was not a simple term. In Brazil, physicians adhered to both psychiatric and racial definitions, with danger coming from both familial defects independent of phenotype and the racial mixing of the Brazilian population. These competing understandings would not disappear with the arrival of the eugenics movement of the 1910s and 1920s. After the firm separation of medical specialties, however, obstetricians stopped believing that sterilisation caused psychiatric disturbances in women, although they continued to reject the practice in relation to any racial arguments. Psychiatrists, nevertheless, argued that sterilisation was necessary to prevent both racial and psychiatric degeneration. Yet women almost never appeared as primary actors in discussions about the permanent privation of their reproductive functions. It is clear, however, that women wanted to access sterilisation treatments and tried to prevent conception through the methods that Abel Parente once advertised in the city's newspaper. These glimpses of agency show cracks in the medical system physicians worked to consolidate, and fleeting moments in the real lives of the women whose bodies featured so centrally in elite men's prescriptions for the Brazilian nation. 